\title{
PENGEMBANGAN MEDIA PEMBELAJARAN MENGGUNAKAN MULTIMEDIA INTERAKTIF LECTORA INSPIRE
}

\author{
Desy Mandasari; Kholilur Rahman; Riza Faishol \\ Institut Agama Islam Ibrahimy Genteng Banyuwangi, Indonesia \\ E-mail: mandasari@gmail.com; kholilur@iaiibrahimy.ac.id; riza@iaiibrahimy.ac.id
}

\begin{abstract}
Abstrak: Media pembelajaran merupakan alatbantu yang sengaja digunakan sebagai perantara antara guru dan siswa dalam memahami materi pelajaran agar lebih efektif dan efisien. Dalam pembelajaran Guru dituntut untuk mampu menciptakan pembelajaran yang inovatif dan lebih menarik dalam pembelajaran, salah satu cara menciptakan pembelajaran yang inovatif dan menarik yaitu menggunakan media pembelajaran. Salah satu media pembelajaran yang saat ini sedang dikembangkan oleh dunia pendidikan yaitu multimedia interaktif Lectora Inspire. Penelitian ini bertujuan untuk menghasilkan produk media pembelajaran interaktif pada mata pelajaran Fiqih bab shalat dalam keadaan darurat yang valid digunakan, mengetahui efektifitas penggunaannya. Locus riset ini adalah MTs Al-Kutsar Srono. Penelitian ini menggunakan metode penelitian pengembangan R\&D (Research and Development) yang telah diadaptasi menjadi 9 tahap, yaitu (1) Potensi Masalah, (2) Pengumpulan Data dan Analisis Kebutuhan, (3) Desain Produk, (4) Validasi Desain oleh ahli, (5) Revisi Desain, (6) Uji Coba Produk, (7) Revisi Produk, (8) Uji Coba Pemakaian, (9) Revisi Produk, dan terakhir Hasil Akhir Produk. Hasil penelitian yang diperoleh adalah media pembelajaran yang dikemas dalam bentuk Compact disc (CD) dengan nama Materi Shalat dalam Keadaan Darurat. Validasi media dilaksanakan untuk menghasilkan produk media pembelajaran yang layak digunakan. Validasi yang dilakukan ada 3 aspek keahlian yaitu: ahli media, ahli materi, dan guru bidang studi. Hasil validasi media menunjukkan bahwa prosentase ahli media $88 \%$, ahli materi $88 \%$, guru bidang studi $82 \%$. Respon siswa terhadap media pembelajaran dinyatakan sangat baik dengan hasil prosentasi 96,2\%. Untuk mengetahui efektifitas penggunaan media lectora digunakan perhitungan hasil pre-test dan post-test menggunakan SPSS versi 20. Berdasarkan hasil uji t diperoleh nilai Sig. 0,000 < 0,05 maka HO ditolak dan HA diterima. Jadi ada perbedaan yang signifikan antara hasil pre-test dan post-test. Sehingga media lectorainspire efektif digunakan dalam pembelajaran Fiqih kelas VII di MTs Al-Kautsar Srono.
\end{abstract}

Kata kunci: Media pembelajaran, Multimedia Interaktif Lectora Inspire

\section{Pendahuluan}

Keberhasilan guru dalam proses belajar mengajar erat kaitannya dengan metode, model, strategi, sumber belajar dan media pembelajaran. Untuk mendapatkan proses pembelajaran yang menarik dan interaktif maka guru perlu memiliki metode, model, strategi, sumber belajar dan media pembelajaran serta pendekatan yang sesuai dengan keadaan dan kebutuhan siswa. Hal ini bertujuan agar proses pembelajaran berjalan dengan baik. Salah satu faktor penting yang mempengaruhi keberhasilan guru dalam mengajar yaitu penggunaan media pembelajaran yang menarik dan interaktif. Sehingga murid lebih tertarik untuk mendengarkan dan memperhatikan pembelajaran ketika proses belajar mengajar berlangsung. Pemilihan media yang tepat dan sesuai dengan kondisi siswa akan membuat pembelajaran di kelas lebih efektif. 
Media secara luas dapat diartikan sebagai manusia, benda, ataupun peristiwa yang yang memungkinkan anak didik memperoleh pengetahuan dan ketrampilan. Hadirnya media dalam pembelajaran memiliki peran yang cukup penting untuk menunjang kesuksesan dan kelancaran proses belajar mengajar, karena media berfungsi sebagai perantara dan pembantu apabila kerumitan atau ketidakjelasan yang dapat disederhanakan dengan bantuan media. ${ }^{1}$ Media dapat mewakili apa yang kurang mampu guru ucapknan melalui kata-kata atau kalimat tertentu. Bahkan keabstrakan bahan-bahan pelajaran dapat dikonkretkan dengan adanya media. Dengan demikian siwa akan lebih mudah dalam memahami suatu pelajaran karena siswa dapat melihat gambaran secara konkret dengan adanya bantuan media.

Seiring berkembangnya zaman perkembangan teknologi di Indonesia juga semakin berkembang. Perkembangan Teknologi Informasi memacu suatu cara baru dalam kehidupan. Kemajuan teknologi informasi dan telekomunikasi yang begitu pesat memungkinkan diterapkannya cara-cara baru yang lebih efektif dan efisien sehingga dapat meningkatkan produktifitas. Perkembangan teknologi informasi memperlihatkan bermunculannya berbagai jenis kegiatan yang berbasis teknologi, termasuk di dalamnya dalam hal pendidikan.

Salah satu produk IT yang berbasis pendidikan yaitu Media Pembelajaran Interaktif. Media interaktif merupakan salah satu produk berbasis TIK yang dimanfaatkan sebagai media dalam pembelajaran yang dapat memudahkan dan membangkitkan minat belajar siswa dalam pembelajaran

Sampai saat ini media pembelajaran interaktif belum berkembang dengan optimal di Indonesia. Salah satu kendala pengembangan media pembelajaran interaktif adalah kurang dikuasainya teknologi pengembangan media interaktif oleh para pengajar, sehingga pengembangan materi pembelajaran interaktif dengan komputer kurang optimal. ${ }^{2}$

Masih banyak peserta didik yang kurang fokus pada saat pembelajaran berlangsung. Hal ini bisa dilihat dari sikap mereka yang suka mengobrol, bermain, mengantuk pada saat jam belajar berlangsung, ini diakibatkan karena metode yang digunakan masih cenderung pada metode ceramah dan berfokus pada buku teks sehingga peserta didik merasa bosan. Oleh karena itu guru dituntut untuk mampu menciptakan pembelajaran yang inovatif dan lebih menarik. Salah satunya dengan membuat media pembelajaran interaktif dengan Lectora inspire.

Software Lectora Inspire merupakan perangkat lunak Authoring Tool untuk pengembangan konten e-learning yang dikembangkan oleh Trivantis Corporation, sebuah perusahaan dari Australia. Setelah diproduksi dan dirilis pada tahun 1999, pada tahun 2000 lectora menjadi software

\footnotetext{
${ }^{1}$ Syaiful Bahri dan Zain, Azwan,Strategi Belajar Mengajar (Rineka Cipta: Jakarta, 2010), 120.

${ }^{2}$ Sulaiman Fiqh Islam (Sinar Baru Algesindo: Bandung, 2014), 102.
} 
pertama sebagai sistem authoring AICC yang besertifikat di pasar. Berkat pencapaian luar biasa ini Lectora semakin mendapatkan kredibilitas untuk penerimanya terutama dalam industry e-learning. Lectora Inpire dapat digunakan untuk membuat berbagai konten, diantaranya yaitu konten website, kursus pelatihan online, konten e-learning, game edukatif, dan presentasi interaktif. 3

Lectora Inspire merupakan softwarepengembangan belajar yang relatif mudah diterapkan. Karena tidakmemerlukan bahasa pemrograman yang canggih. Alasan lain kenapa penelitian ini menggunakan software lectora inspire sebagai media pembelajaran karena media berbasis lectora inspire dapat memudahkan guru dalam membuat media pembelajaran yang intektif dan menyenangkan. Karena di dalam lectora dapat dengan mudah menambahkan animasi, audio, dan video didalamnya, selain itu denganmenggunakan lectora inspire kita dapat membuat dengan mudah soal evaluasiyang bervariasi mulai dari pilihan ganda, benar salah, isian singkat,mencocokkan/menjodohkan, soal tarik dan tempatkan, dan soal penentuan lokasi, selain tersedia banyak bentuk game edukatif yang dapat membuat suasana pembelajaran di kelas lebih menyenangkan.

Namun penggunaan multimedia dalam pembelajaran tentu memerlukan cost atau biaya. Karena dalam penggunaan multimedia dibutuhkan fitur-fitur ataupun alat-alat pendukung seperti komputer atau laptop. Ketika siswa ingin belajar menggunakan multimedia secara mandiri di rumah, maka siswa juga harus memiliki komputer atau laptop untuk dapat membuka dan mempelajari materi-materi yang terdapat pada multimedia.

Berdasarkan hasil observasi yang peneliti lakukan, peneliti dapati bahwa di MTs AlKautsar Srono belum pernah menggunakan media pembelajaran menggunakan multimedia pembelajaran interaktif lectora inspire terutama dalam pembelajaran Pendidikan Agama Islam. Oleh sebab itu peneliti berupaya mengembangkan media yang berbasis pada multimedia pembelajaran interaktif lectora inspire pada mata pelajaran fiqih pada babshalat dalam keadaan darurat.

Berdasarkan uraian di atas, maka timbul keinginan penulis untuk meneliti tentang pengembangan media pembelajaran bebasis lectora inspire karena merupakan hal yang menarik dan perlu dikembangkan saat ini.

\section{Metode}

Penelitian ini merupakan pengembangan. Penelitian pengembangan atau dalam Bahasa Inggris biasa disebut dengan Reseach and Development adalah metode penelitian yang digunakan untuk menghasilkan produk tertentu, serta menguji keefektifan dari produk tersebut. Untuk dapat

\footnotetext{
${ }^{3}$ Fasthea, Sholeh, dkk. Merancang Desain Multimedia Pembelajan Interaktif Menggunakan Software Lectora Inspire, (UIN Sunan Kalijaga: Yogyakarta, 2015), 104.
} 
menghasilkan produk tertentu digunakan penelitian yang bersifat analisis dan untuk menguji keefektifan dari produk tersebut supaya dapat berfungsi di masyarakat luas, maka perlu adanya dilakukan penelitian untuk menguji kefektifan dari produk tersebut. ${ }^{4}$

Adapun langkah-langkah model pengembangan $R \& D$ model Borg and adalah sebagai berikut:

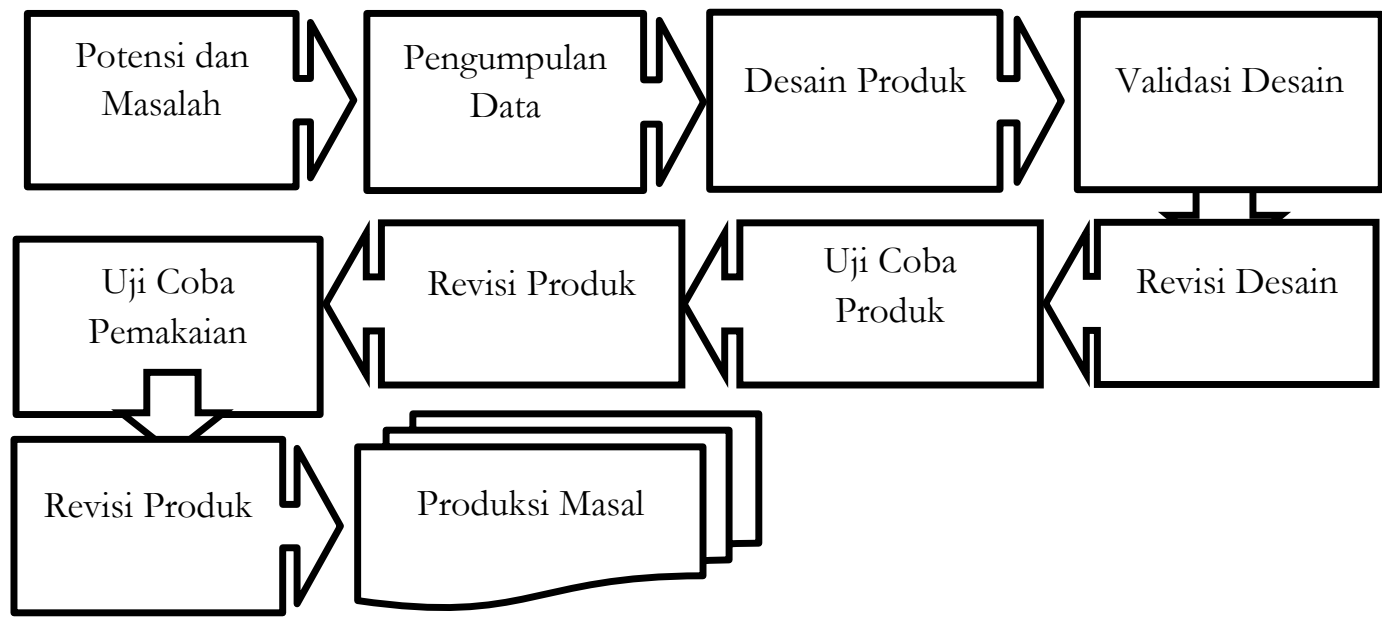

Gambar 1: Langkah-langkah Pengembangan

Dalam menyusun pengembangan media pembelajaran dengan Lectora Inspire penulis melakukan langkah-langkah penelitian berdasarkan model pengembangan media yang dikembangkan oleh Sugiyono, sebagai berikut:1) Potensi Masalah, 2) Pengumpulan Data, 3) Desain Produk, 4) Validasi Desain, 5) Revisi Desain, 6) Uji Coba Produk, 7) Revisi Produk, 8) Uji Coba Pemakaian, 9) Revisi Produk, 10) Produk Masal.

Sesuai dengan model pengembangan diatas model pengembangan ini tidak menggunakan 10 langkah namun hanya menggunakan 9 langkah, adapun prosedur pengembangan yang ditempuh dalam penelitian pengembangan ini yaitu: 1) Potensi Masalah, 2) Pengumpulan Data dan Analisis Kebutuhan, 3) Desain Produk, 4) Validasi Desain oleh ahli, 5) Revisi Desain, 6) Uji Coba Produk, 7) Revisi Produk, 8) Uji Coba Pemakaian, 9) Revisi Produk dan Hasil Akhir Produk.

Pada penelitian ini, data yang diperoleh adalah berupa data kualitatif dan kuantitatif. Data kualitatif diperoleh dari hasil Analisa dan tanggapan serta saran dari ahli media, ahli materi , guru mata pelajaran, siswa kelas VII MTs Al-Kautsar, hasil observasi dan hasil wawancara. Sedangkan data kuantitatif diperoleh dari instrumen pengumpulan data yang dianalisa dengan teknik analisa dan prosentase. Analisis data dilakukan untuk memperoleh pemahaman yang konkret tentang keberhasilan media interaktif lectora inspire yang telah dikembangkan.

\footnotetext{
4 Paul Suparno"Riset Tindakan untuk Pendidik” (PT Grasindo: Jakarta, 2018),298.

40 | Tarbiyatuna: Jurnal Pendidikan Islam; Volume 13, Nomor 1, Februari 2020 


\section{Studi Pendahuluan}

Hasil studi pendahuluan dilakukan untuk menganalisis kebutuhan pengembangan multimedia interaktif lectora inspire pada mata pelajaran fiqih bab shalat dalam keadaan darurat. Pengembangan ini dimaksudkan untuk mengatasi kesenjangan kondisi ideal dengan kondisi nyata yang ada dilapangan khususnya pada masalah: a) Ketersedian multimedia interaktif lectora inspire, b) Ketersediaan media, c) Mengatasi kondisi pembelajaran fiqih yang dalam upaya meningkatkan keefektifan pembelajaran fiqih khusunya pada bab shalat dalam keadaaan darurat.

1. Analisis Ketersediaan Multimedia Interaktif Lectora Inspire

Identifikasi multimedia pembelajaran interaktif lectora inspire diperoleh dari guru fiqih kelas VII di MTs Al-Kautsar Srono. Dari hasil identifikasi belum ada multimedia interaktif yang dikembangkan pada sekolah tersebut dan guru hanya memakai buku LKS dan buku fiqih pegangan guru, serta menggunakan media powerpoint ketika diperlukan saja.

Analisis multimedia interaktif yang dipakai sebagai rujukan utama dalam pembelajaran fiqih di MTs Al-Kautsar, ditemukan bahwa belum adanya multimedia interaktif yang digunakan terutama multimedia interaktif lectora inspire. Dan media pengajaran yang digunakan saat ini masih berupa buku wajib yang diterapkan disekolah tersebut, serta powerpoint.

2. Ketersediaan Media

Dari berbagai macam media yang digunakan oleh guru dan siswa dalam pembelajaran, dilakukan penilaian media berdasarkan unsur-unsur komponen dan karakteristik pembelajaran fiqih. Berdasarkan data hasil penilaian guru mata pelajaran fiqih, analisis dengan perhitungan presentase yaitu:

a. Kesesuaian media pembelajaran yang dipilih dengan materi pengajaran atau jenis kegiatan yang akan dilakukan oleh siswa sebesar 80\% (Baik).

b. Kemudahan dalam memperoleh alatnya dan dalam perancangannya $80 \%$ (Baik).

c. Kemudahan dalam penggunaannya $80 \%$ (Baik).

d. Terjamin keamanan dalam penggunaannya 80\% (Baik).

e. Kemampuan dana 80\% (Baik).

f. Terdapat tes atau evaluasi didalam media pembelajaran di kelas 40\% (Sangat Kurang Baik).

g. Kemudahan dalam penyimpanan, pemeliharaan, dan sebagainya $80 \%$ (Baik).

Dengan demikian, dapat diketahui bahwa media pembelajaran yang saat ini digunakan oleh guru mata pelajaran fiqih sudah cukup baik, namun pada media yang digunakan saat ini tidak terdapat evaluasi atau penilaian didalam media yang digunakan, sehingga komponen ini hanya memiliki prosentase sebanyak $40 \%$. Selain itu media yang digunakan masih bersifat 
media pembelajaran satu arah dan masih kurang memadai sebagai media pembelajaran. Selain itu, berdasarkan temuan tersebut dapat dikatakan bahwa saat ini masih belum tersedianya multimedia interaktif lectora inspire untuk pembelajaran fiqih terutama pada bab shalat dalam keadaan darurat.

3. Kondisi Pembelajaran Fiqih

Analisis kondisi pembelajaran fiqih dimaksudkan untuk mendeskripsikan kondisi empiris pembelajaran fiqih di MTs Al-Kautsar Srono yang dihimpun melalui angket dan hasil observasi. Berdasarkan angket guru dari 6 indikator kendala dalam pembelajaran terdapat 3 indikator yang menjadi kendala pembelajaran fiqih yaitu partisipasi siswa dalam pembelajaran fiqih yang masih rendah dan iklim pembelajaran dikelas yang kurang kondusif seperti masih banyak siswa yang mengantuk ketika pembelajaran berlangsung, serta pemahaman siswa terhaadap materi yang telah disampaikan menggunakan media yang digunakan guru masih rendah. Hal ini terjadi karena belum adanya multimedia interaktif yang menarik.

4. Pengembangan Produk

Penelitian ini memilih materi pembelajaran fiqih bab shalat dalam keadaan darurat dengan kompetensi dasar yaitu memahami ketentuan shalat dalam keadaan sakit dan shalat di kendaraan, kemudian materi tersebut diimplementasikan kedalam Rencana Pelaksanaan Pembelajaran (RPP), setelah menyusun RPP dilanjutkan dengan membuat storyboard, dan mengumpulkan materi yang akan digunakan dalam menyusun media pembelajaran dengan lectora inspire.

\section{Media Lectora Inspire}

Adapun tampilan materi pembelajaran dalam media yang dikembangkan ini yaitu:

1. Halaman Awal

Halaman atau bagian awal dari media pembelajaran merupakan tampilan selamat datang yang terdapat gambar anak laki-laki berseragam SMP yang seolah-olah mengucapkan selamat datang pada multimedia interaktif lectora inspire pada materi shalat dalam keadaan darurat di pembelajaran fiqih untuk kelas VII MTs Al-Kautsar, dan disertai pula nama dari pengembang media. 


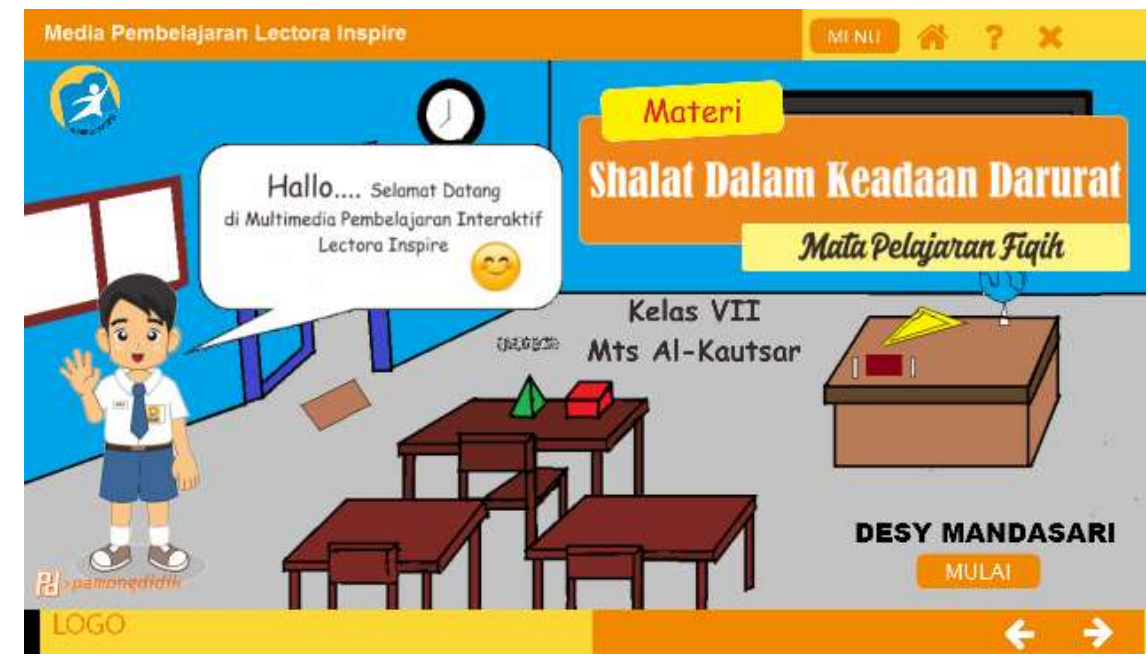

Gambar 2: Halaman Awal

2. Petunjuk Penggunaan

Terdapat dua slide pada bagian petunjuk penggunaan, yaitu petunjuk penggunaan tombol navigasi dan petunjuk penggunaan menu utama. Petunjuk penggunaan tombol navigasi berisi tentang penjelasan tombol-tombol navigasi yang terdapat pada setiap bagian slide dalam media lectora inspire. Kemudian pada petunjuk penggunaan tombol menu utama berisi tentang penjelasan tombol yang ada pada menu utama.

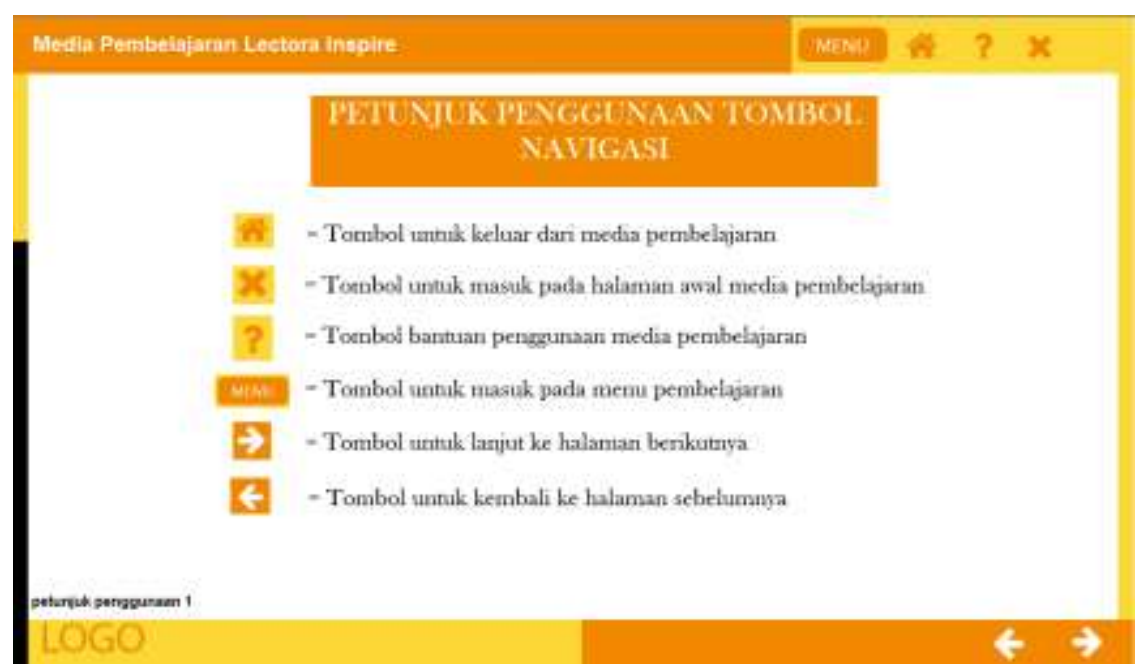

Gambar 3: Petunjuk Penggunaan Tombol Navigasi 


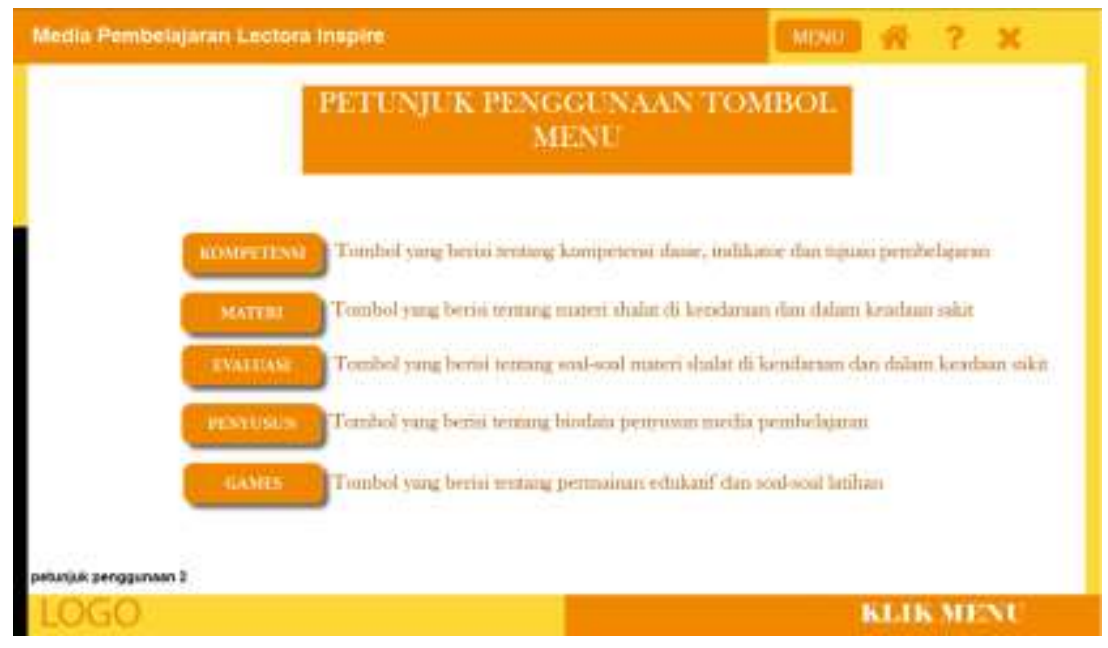

Gambar 4: Petunjuk Penggunaan Tombol Menu Utama

3. Menu Utama

Bagian menu utama berisi tentang pembahasan mengenai shalat dalam keadaan darurat, adapun tombol-tombol yang ada pada menu utama adalah kompetensi, materi, evaluasi, biografi peyusun, dan games.

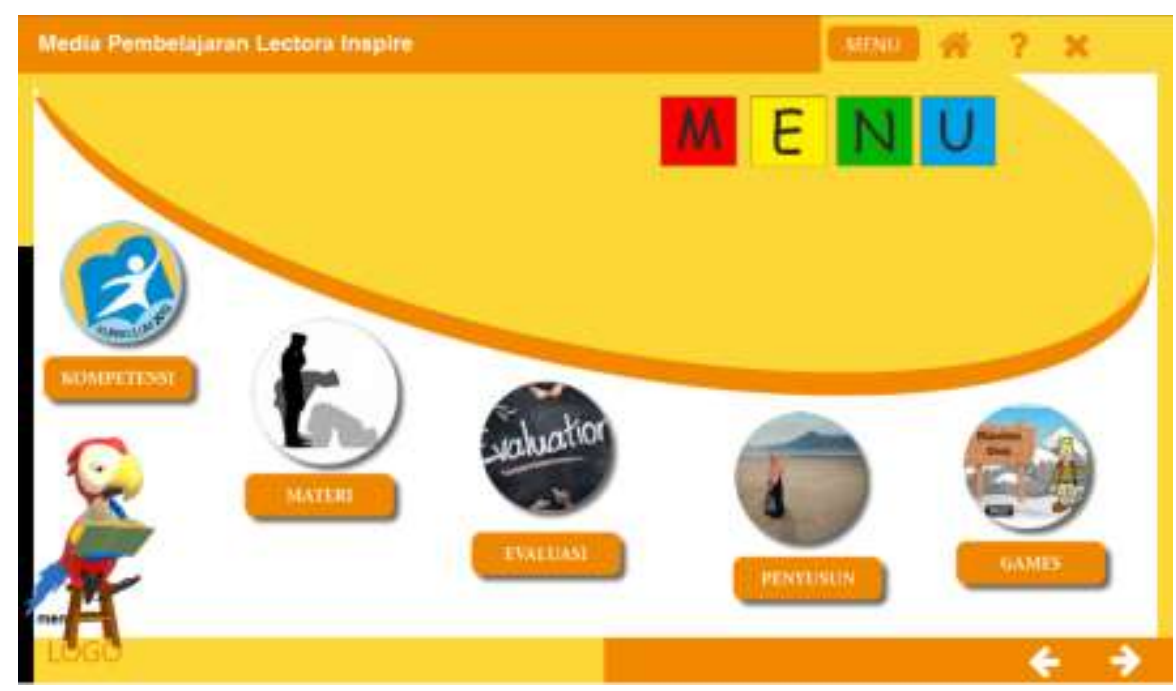

Gambar 5: Menu Utama

4. Kompetensi

Bagian kompetensi berisi tentang kompetensi dasar, indikator dan tujuan pembelajaran yang akan dipelajari. Berikut adalah gambar bagian media yang memuat tentang kompetensi. 


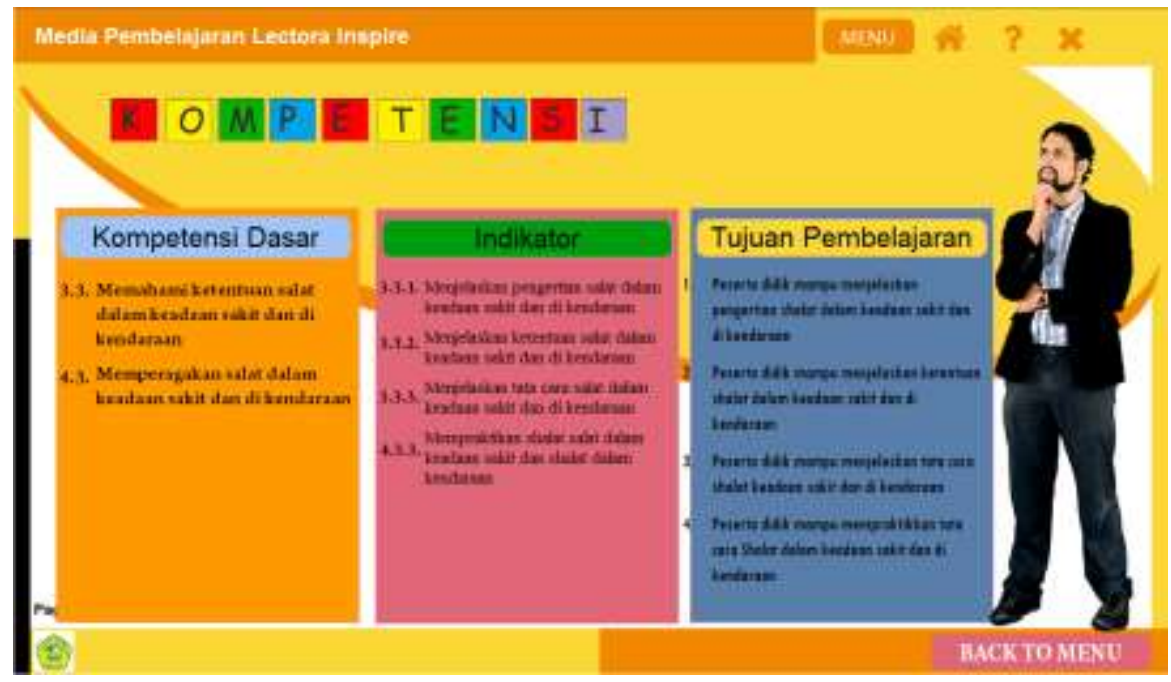

Gambar 6: Kompetensi

5. Materi

Bagian materi berisi tentang materi shalat dalam keadaan darurat yang terdiri dari shalat dalam kendaraan dan shalat dalam keadaan sakit. Yang berisi tentang pengertian, halhal yang harus diperhatikan selama shalat dalam kendaraan maupun shalat dalam keadaan sakit, srta tata cara melaksanakan shalat dalam kendaraan dan shalat dalam keadaan sakit, yang mana penjelasan dari materi juga dilengkapi dengan teks, gambar, dan video.

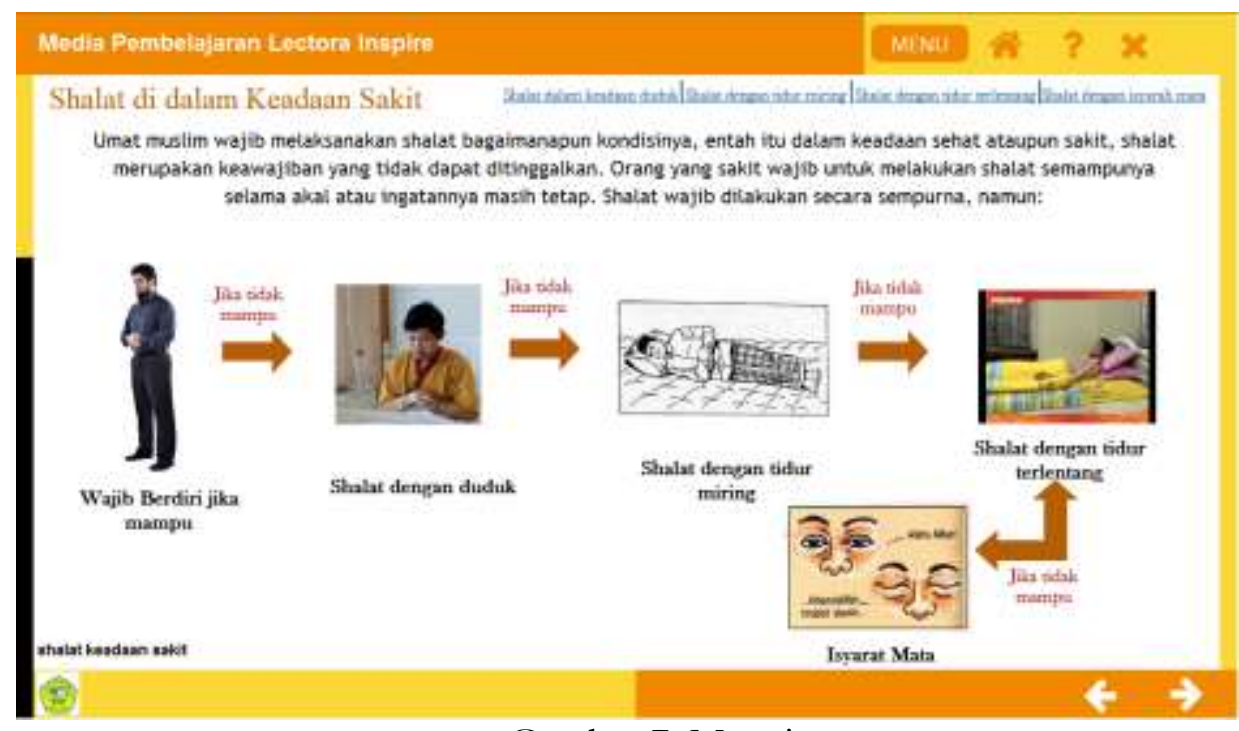

Gambar 7: Materi

6. Evaluasi

Bagian evaluasi berisi tentang soal-soal shalat dalam kendaraan dan shalat dalam keadaan sakit. Yang mana siswa dapat langsung menjawab pertanyaan pada media dan dapat langsung mengetahui hasil dari jawaban yang telah dipilih. 


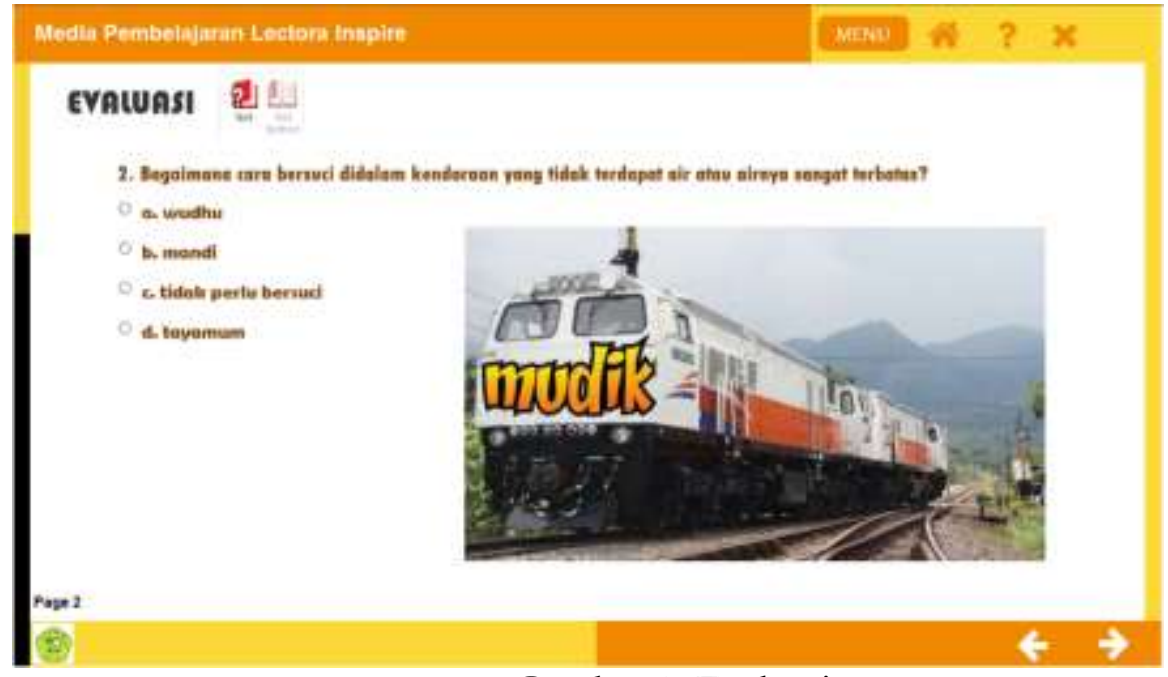

Gambar 8: Evaluasi

7. Permainan

Berisi tentang soal-soal latihan yang dikemas dalam bentuk permainan. Layaknya permainan game pada umumnya siswa akan diberikan pertanyaan, jawaban benar atau salah maka akan mendapatkan feedback sesuai jawaban yang telah diberikan.

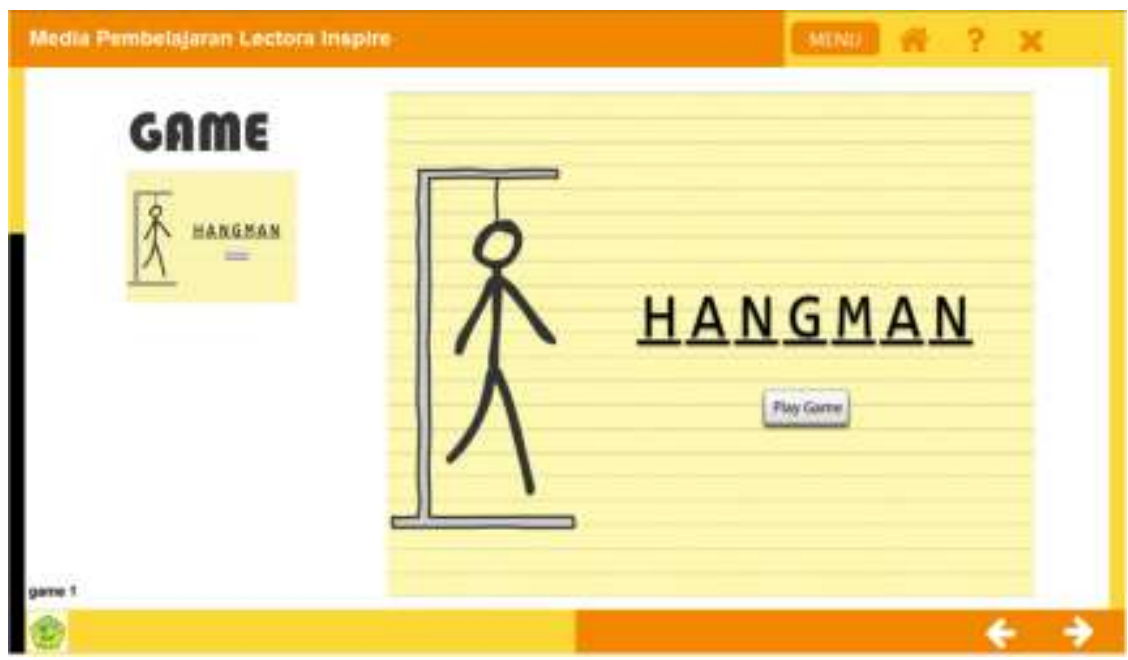

Gambar 9: Soal Permainan 1

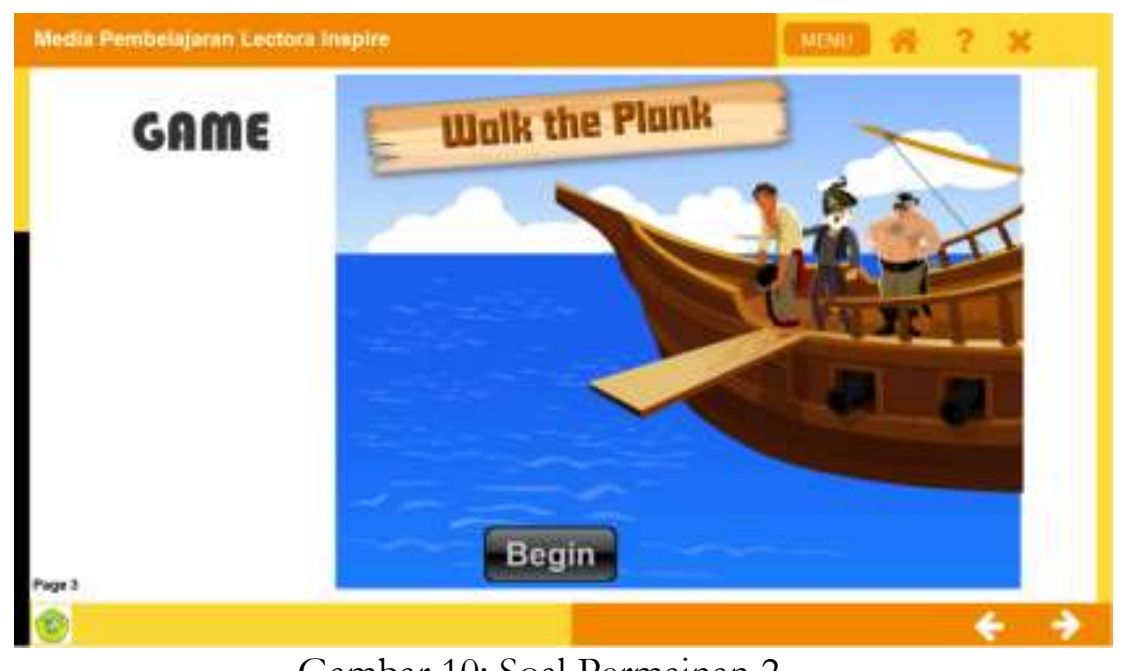

Gambar 10: Soal Permainan 2 


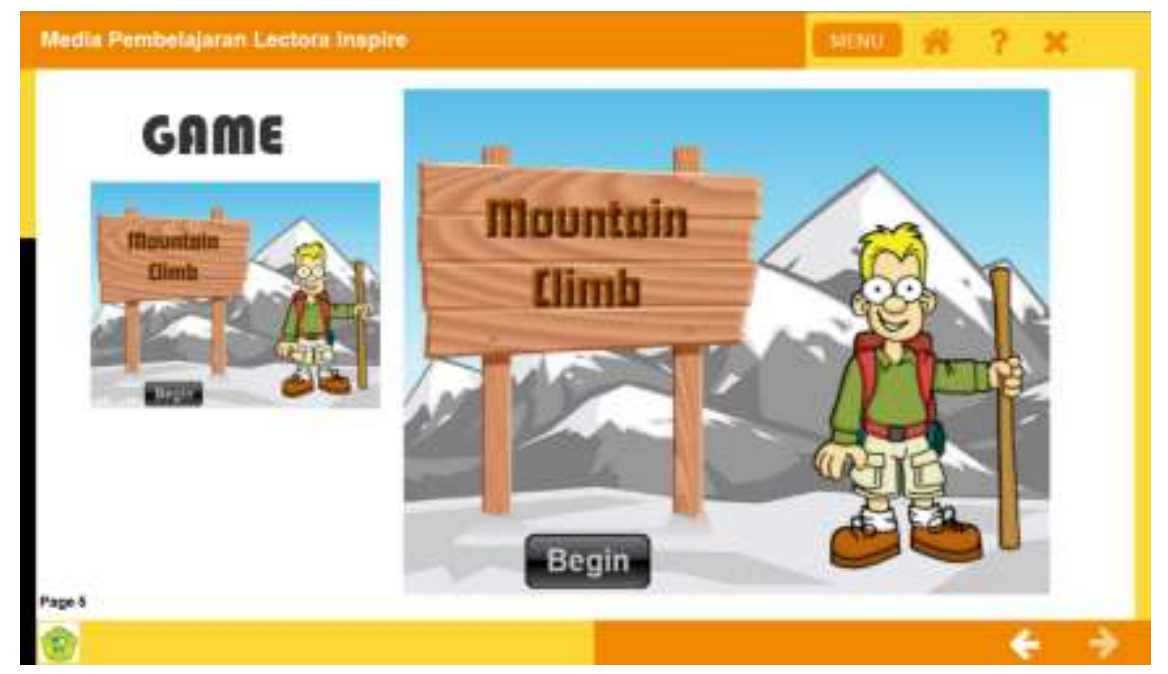

Gambar 11: Soal Permainan 3

\section{Analisis dan Hasil Uji Coba}

Pada analisis data terdiri dari penilain kualitas media lectora yang telah dikembangkan. Hasil uji coba yang akan diuraikan pada bagian ini meliputi: (1) Data uji coba ahli materi, (2) Data uji coba ahli media, (3) Data uji coba pengguna (Guru fiqih MTs Al-Kautsar Srono), (4) Data uji coba lapangan (Siswa kelas VII MTs Al-Kautsar Srono), dan (5) Hasil belajar siswa dengan menggunakan produk pengembangan menggunakan multimedia interaktif lectora inspire untuk pembelajaran fiqih bab shalat dalam keadaan darurat.

1. Data Uji Coba Ahli Materi

Berikut ini akan dipaparkan secara deskriptif hasil penilaian ahli materi terhadap produk pengembangan multimedia interaktif lectora inspire untuk pembelajaran fiqih bab shalat dalam keadaan darurat sebagai media pembelajaran. Aspek yang dinilai dari materi shalat dalam keadaan darurat pada mata pelajaran fiqih menggunakan lectora inspire yaitu: (1) Kedalaman isi materi, (2) Kesesuaian bahasa, (3) Kejelasan isi materi, (4) Kesesuaian latihan soal dengan materi, (5) Memudahkan memahami isi materi, (6) Kejelasan latihan soal, (7) Kesesuaian materi dengan RPP, (8) Kelengkapan isi materi, (9) Kejelasan dan keruntutan penyajian materi, (10) Penggunaan bahasa dalam penjelasan materi.

Data hasil uji coba materi menggunakan angket yang meliputi 10 aspek penilaian. Setiap aspek memiliki skor tertinggi 5 dan skor terendah 1. Adapun hasil uji coba dari ahli materi adalah rata-rata baik.

Berdasarkan data yang dihimpun melalui angket, maka dapat dihitung presentase tingkat kelayakan multimedia interaktif lectora inspire dengan rumus sebagai berikut:

$$
\text { Presentase }=\frac{\text { jumlah skor jawaban responden }}{\text { jumlah skor ideal }} \times 100 \%
$$


Terdapat 10 aspek yang dinilai dengan skor antara 1 sampai 5, maka jika aspek yang dinilai sebanyak 10 butir maka jumlah skor ideal yang diperoleh adalah 50 .

Berdasarkan ketentuan diatas, maka secara keseluruhan dapat dihitung presentase tingkat pencapaian multimedia interaktif lectora inspire sebagai berikut:

Presentase $=\frac{44}{50} \times 100 \%=88 \%$

Bila dicocokkan dengan table kelayakan yang sudah ditetapkan, maka angka presentase yang didapatkan berada pada kualifikasi baik namun ada beberapa bagian yang perlu direvisi. Adapun data kualitatif yang dihimpun dari komentar dan saran ahli materi dalam pertanyaan terbuka yang berkenaan dengan multimedia interaktif akan dipaparkan pada table berikut ini.

Tabel Ihtisar Data Penilaian Ahli Materi Terhadap Media yang Dikembangkan

\begin{tabular}{|c|c|c|}
\hline No & Komentar & Saran \\
\hline 1. & $\begin{array}{l}\text { Pembelajaran menggunakan lectora sangat } \\
\text { bagus dan membantu peserta didik untuk } \\
\text { memotivasi, menarik minat belajar dan } \\
\text { memudahkan siswa memahami materi. }\end{array}$ & $\begin{array}{l}\text { Perlu adanya pengenalan terlebih } \\
\text { dahulu antara media lectora dengan } \\
\text { praktik pembelajaran agar lebih bisa } \\
\text { memahami. }\end{array}$ \\
\hline
\end{tabular}

2. Data Uji Coba Ahli Media.

Aspek yang dinilai dari ahli media pada materi shalat dalam keadaan darurat pada mata pelajaran fiqih menggunakan lectora inspire yaitu: (1) Kesesuain warna background dengan warna teks, (2) Kesesuaian tampilan gambar, video, ukuran tulisan dan tipe huruf. (3) Ketepatan dalam penempatan tombol navigasi, (4) Kualitas video, gambar dan suara (audio), (5) Ketepatan dalam tata letak tampilan, (6) Kemudaham dalam penggunaan media, (7) Penjelasan petunjuk penggunaan tombol, (8) Kejelasan materi, (9) Kesesuain gambar ilustrasi dengan materi, (10) Bahasa yang digunakan mudah dipahami.

Berikut akan disajikan paparan secara deskriptif hasil tinjauan ahli media terhadap produk pengembangan multimedia interaktif lectora inspire pada mata pelajaran fiqih bab shalat dalam keadaan darurat pad akelas VII MTs Al-Kautsar Srono rata-rata baik.

Berdasarkan data yang dihimpun melalui angket, maka dapat dihitung presentase tingkat kelayakan multimedia interaktif lectora inspire dengan rumus sebagai berikut:

Presentase $=\frac{\text { jumlah skor jawaban responden }}{\text { jumlah skor ideal }} \times 100 \%$

Karena angket yang disiapkan oleh peneliti terdiri dari 10 aspek yang dinilai dengan skor antara 1 sampai 5, maka jika aspek yang dinilai sebanyak 10 butir maka jumlah skor ideal yang diperoleh adalah 50 . 
Berdasarkan ketentuan diatas, maka secara keseluruhan dapat dihitung presentase tingkat pencapaian multimedia interaktif lectora inspire sebagai berikut:

Presentase $=\frac{44}{50} \times 100 \%=88 \%$

Bila dicocokkan dengan table kelayakan yang sudah ditetapkan, maka angka presentase yang didapatkan berada pada kualifikasi baik namun ada beberapa bagian yang perlu direvisi.

3. Data Uji Coba Pengguna (Guru fiqih MTs Al-Kautsar Srono)

Berdasarkan data yang dihimpun melalui angket, maka dapat dihitung presentase tingkat kelayakan multimedia interaktif lectora inspire dengan rumus sebagai berikut:

Presentase $=\frac{\text { jumlah skor jawaban responden }}{\text { jumlah skor ideal }} \times 100 \%$

Karena angket yang disiapkan oleh peneliti terdiri dari 10 aspek yang dinilai dengan skor antara 1 sampai 5, maka jika aspek yang dinilai sebanyak 10 butir maka jumlah skor ideal yang diperoleh adalah 50 .

Berdasarkan ketentuan diatas, maka secara keseluruhan dapat dihitung presentase tingkat pencapaian multimedia interaktif lectora inspire sebagai berikut:

Presentase $=\frac{41}{50} \times 100 \%=82 \%$

Bila dicocokkan dengan table kelayakan yang sudah ditetapkan, maka angka presentase yang didapatkan berada pada kualifikasi baik namun ada beberapa bagian yang perlu direvisi.

4. Data Uji Coba Lapangan

Uji coba lapangan dilakukan oleh siswa kelas VII MTs Al-Kautsar Srono yang terdiri dari 34 siswa pada mata pelajaran fiqih bab shalat dalam keadaan darurat. Data hasil uji coba lapangan dihimpun dengan menggunakan angket.

a. Penyajian Data

Berikut ini akan disajikan paparan deskriptif hasil tinjauan ahli lapangan (siswa) terhadap produk pengembangan multimedia interaktif lectora inspire dalam memahami mata pelajaran fiqih bab shalat dalam keadaan darurat. Adapun aspek uji coba lapangan terhadap media yang dikembangkan yaitu: (1)Meteri pembelajaran shalat dalam keadaan darurat menarik bagi saya, (2) Materi dalam media pembelajaran dapat saya pahami dengan jelas, (3) Materi shalat dalam keadaan darurat lengkap, (4) Penggunaan bahasa dalam media pembelajaran mudah saya pahami, (5) Terdapat evaluasi dalam pembelajaran, (6) Ukuran dan jenis huruf yang digunakan dalam media mudah saya baca, (7) Gambar dan video dalam media jelas, (8) Tampilan dalam media menarik bagi saya, (9) Saya merasa terbantu dalam memahami materi dengan media Lectora Inspire, (10) Game edukatif pada Lectora Inspire menarik dan menyenangkan bagi saya. 
Berdasarkan tabel 4.10 yang dihimpun melalui angket, maka dapat dihitung presentase tingkat kelayakan multimedia interaktif lectora inspire dengan rumus sebagai berikut:

$$
\text { Presentase }=\frac{\text { jumlah skor jawaban responden }}{\text { jumlah skor ideal }} \times 100 \%
$$

Terdapat 10 aspek yang telah disiapkan dalam angket dengan skor nilai antara 1 sampai 5, maka jika 10 aspek dikalikan 5 maka jumlah skor ideal yang diperoleh adalah 50 .

Berdasarkan ketentuan rumus diatas, selanjutnya hasil perhitungan angket dicocokan dengan table kelayakan yang sudah ditetapkan. Dari 10 aspek penilaian oleh 34 siswa maka diperoleh data sebagai berikut yaitu: (1) Meteri pembelajaran shalat dalam keadaan darurat menarik bagi saya memiliki presentase $96,47 \%$, (2) Materi dalam media pembelajaran dapat saya pahami dengan jelas 95,83\%, (3) Materi shalat dalam keadaan darurat lengkap 93,52\%, (4) Penggunaan bahasa dalam media pembelajaran mudah saya pahami 97,64\%, (5) Terdapat evaluasi dalam pembelajaran $98,23 \%$, (6) Ukuran dan jenis huruf yang digunakan dalam media mudah saya baca 90,00\%, (7) Gambar dan video dalam media jelas 97,05\%, (8) Tampilan dalam media menarik bagi saya $97,05 \%$, (9) Saya merasa terbantu dalam memahami materi dengan media Lectora Inspire 98,23\%, (10) Game edukatif pada Lectora Inspire menarik dan menyenangkan bagi saya 96,64\%.

Presentase $=\frac{1635}{1700} \times 100 \%=96,18 \%$

Dari data yang diperoleh kemudian dicocokan dengan tabel kelayakan yang sudah ditetapkan maka presetase kelayakan media berada pada kualifikasi sangat baik sehingga media siap dimanfaatkan di lapangan sebenarnya untuk kegiatan pembelajaran.

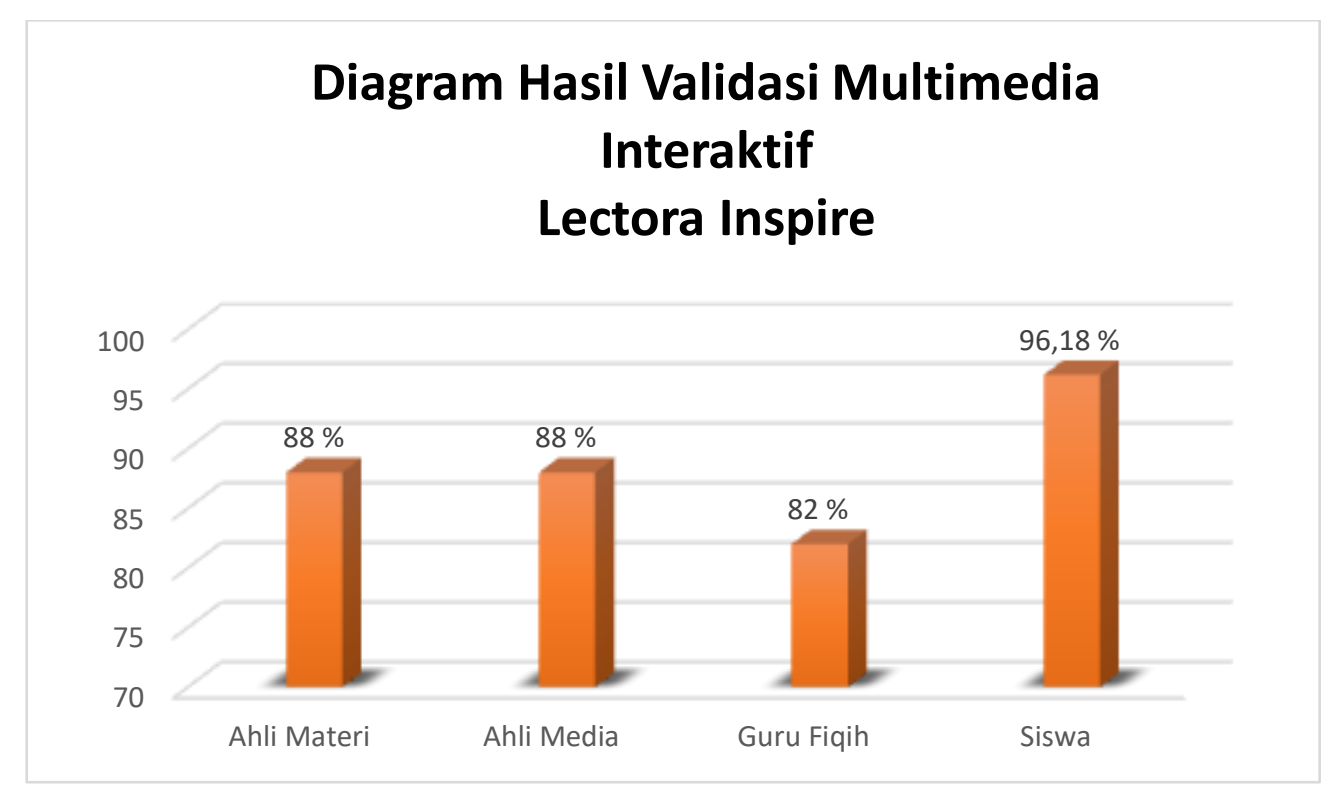

Gambar 2.2. Diagram Hasil Validasi 
b. Hasil Belajar Siswa

Hasil belajar siswa diperoleh saat mengerjakan evaluasi pada uji coba kelas VII Mts Al-Kautsar yang berjumlah 34 siswa. Berdasarkan data yang diperoleh peneliti dapat diketahui bahwa rata-rata perolehan nilai pro-test adalah 56,8\%. Sedangkan rata-rata nilai post-test yaitu 88,8\%. Berdasarkan data ini diperoleh hasih bahwasannya terdapat peningkatan hasil post-test.

Upaya menilai tingkat keefektifan produk pengembangan dilakukan dengan cara membandingkan hasil pretest dan posttest. Untuk mengetahui apakah terdapat perbedaan yang signifikan antara hasil pre-test dan post-test yang digunakan dalam pembelajaran maka digunakan perhitungan uji t dengan menggunakan aplikasi SPSS versi 20. Uji t parsial bertujuan untuk mengetahui apakah variabel bebas $(\mathrm{X})$ secara parsial (sendiri) berpengaruh signifikan terhadap variable $(\mathrm{Y})$. Dengan tingkat kepercayaan yang digunakan adalah 95\%, maka nilai $\alpha=0,05$. Dasar pengembilan keputusan untuk uji t ini yaitu:

(1) Berdasarkan nilai thitung dan t tabel.

- Jika nilai t hitung $<\mathrm{t}$ table maka HO diterima dan HA ditolak.

- Jika nilai t hitung > t table maka HO ditolak dan HA diterima.

(2) Berdasarkan nilai signifikansi hasil output SPSS

- Jika nilai Sig. > 0,05 maka HO diterima dan HA ditolak.

- Jika nilai Sig. < 0,05 maka HO ditolak dan HA diterima.

Berdasarkan ketentuan diatas maka diambil hipotesis (dugaan) dalam uji t yaitu :

(1) $\mathrm{HO}=$ Tidak ada perbedaan yang signifikan antara hasil belajar siswa.

(2) $\mathrm{HA}=$ Ada perbedaan yang signifikan antara hasil belajar siswa.

Berdasarkan perhitungan dengan aplikasi SPSS versi 20 maka didapatkan hasil nilai pre-test dengan $\mathrm{N}=34$ memperoleh Mean 56,76 dengan Std. Deviation 13,19 dan Std. Error Mean 2,26. Kemudian nilai post-test dengan N= 34 memperoleh Mean 88,82 dengan Std. Deviation 12,01 dan Std. Error Mean 2,06. Berdasarkan data hasil uji t diatas diperoleh nilai Sig.(2-tailed) yaitu 0,000. Berdasarkan ketentuan taraf signifikasi 0,05. Maka dapat disimpulkan bahwa nilai Sig. < 0,05 maka HO ditolak dan HA diterima. Jadi ada perbedaan yang signifikan antara hasil pre-test dan post-test.

\section{Revisi Produk Hasil Pengembangan}

Berdasarkan hasil penilaian uji coba produk kepada ahli materi, ahli media, guru bidang studi dan uji coba lapangan (siswa) maka didapatkan data sebagai berikut:

1. Ahli Materi 
Berdasarkan penilaian ahli materi, materi pada produk media yang dikembangkan mendapatkan tingkat penilaian mencapai $88 \%$ yang bila dicocokkan dengan table kelayakan yang sudah ditetapkan, maka angka presentase yang didapatkan berada pada kualifikasi baik. Namun berdasarkan pada hasil angket terbuka ahli materi memberikan komentar dan saran kepada peneliti untuk perlu adanya pengenalan terlebih dahulu antara media lectora dengan praktik pembelajaran agar lebih bisa memahami.

2. Ahli Media

Berdasarkan penilaian ahli media, produk media yang dikembangkan mendapatkan tingkat penilaian mencapai 88\% yang bila dicocokkan dengan tabel kelayakan yang sudah ditetapkan, maka angka presentase yang didapatkan berada pada kualifikasi baik. Namun berdasarkan pada hasil angket terbuka ahli materi memberikan komentar dan saran kepada peneliti untuk memperbaiki tata letak kolom pada drag and drop.

3. Uji Coba Pengguna (Guru Bidang Studi)

Berdasarkan data uji coba pengguna yaitu guru mata pelajaran fiqih , produk media yang dikembangkan mendapatkan tingkat penilaian mencapai $82 \%$ yang bila dicocokkan dengan table kelayakan yang sudah ditetapkan, maka angka presentase yang didapatkan berada pada kualifikasi baik. Namun berdasarkan pada hasil angket terbuka ahli materi memberikan komentar dan saran kepada peneliti untuk memberikan petunjuk penggunaan pada media yang dikembangkan.

\section{Uji Coba Lapangan}

Berdasarkan data uji coba lapangan yaitu siswi kelas VII MTs Al-Kautsar Srono yang berjumlah 34 siswi, produk media yang dikembangkan mendapatkan rata-rata tingkat penilaian mencapai $96,18 \%$ yang bila dicocokkan dengan table kelayakan yang sudah ditetapkan, maka angka presentase yang didapatkan berada pada kualifikasi sangat baik. Namun berdasarkan pada hasil angket terbuka, terdapat komentar dan saran kepada peneliti.

\section{Kajian Produk Akhir}

Produk akhir yang dihasilkan berdasarkan komentar, saran, dan penilaian sari ahli materi, ahli media, guru mata pelajaran fiqih, dan 34 siswa kelas VII MTs Al-Kautsar Srono Bayuwangi. Beberapa bagian dalam media lectora inspire telah direvisi sesuai dengan saran dan komentar yang telah diberikan kepada peneliti. Produk media lectora inspire dikemas dalam sebuah CD (Compact Disk).

\section{Media Lectora Inspire}

Media pembelajaran ini dikembangkan dengan menggunakan aplikasi lectora inspire. Media yang dilengkapi dengan gambar, video, animasi, evaluasi, dan byperlink untuk membuka 
materi pada tiap tombol yang terdapat pada media. Background dibuat dengan gambar animasi yang menarik. Pada halaman awal terdapat animasi anak Sekolah Menengah Pertama (SMP) yang seolah-olah mengucapkan selamat datang pada multimedia interktif lectora inspire. Selain itu media ini juga terdapat permainan yang dapat menarik antusias siswa untuk mengerjakan soal dengan bermain. Media ini berisi halaman awal, petunjuk penggunaan, menu utama, kompetensi, materi shalat dalam keadaan darurat, evaluasi, permainan, dan penyusun.

2. Efektivitas Media Lectora Inspire

Efektifitas adalah suatu pencapaian tujuan yang diinginkan atau dikehendaki melalui serangkaian pilihan cara atau alternative untuk menghasilkan tujuan atau target yang telah ditetapkan. Dimana semakin tinggi presentase target yang dicapai maka semakin efektif pekerjaan yang dilakukan. Efektifitas media lectora yaitu suatu pencapaian tujuan pendidikan yang diinginkan melalui penggunaan media lectora untuk menghasilkan tujuan atau target pembelajaran yang telah ditetapkan. Tujuan atau target pembelajaran yang dimaksudkan disini yaitu pemahaman siswa terhadap materi yang disampaikan saat pembelajaran. Salah satu tolak ukur dari pemahaman siswa terhadap pembelajaran adalah kemampuan mengejakan soal-soal evaluasi dengan benar. Maka dari itu dibuatlah soal pre-test dan post-test untuk mengetahui apakah penggunaaan media lectora berpengaruh terhadap pemahaman siswa pada materi pembelajaran yang diajarkan. Dan apakah media lectora efektif digunakan dalam pembelajaran.

Keefektifan pengunaan media lectora diukur menggunakan soal pre-test dan post-test dimana kemudian dihitung rata-rata hasil perolehan pretest dan postest menggunakan presentase untuk mengetahui hasil soal pre-test dan post-test dan uji t untuk mengetahui apakah perbedaan hasil pre-test dan post-test signifikan atau tidak. Dari perhitungan hasil pre-test dan post-test didapatkan terdapat perbedaan yang signifikan antara hasil pre-test dan post-test, sehingga media lectora inspire efektif digunakan dalam pembelajaran fiqih pada bab shalat dalam keadaan darurat di kelas VII MTS AL-Kautsar Srono.

\section{Kelebihan dan Kekurangan}

1. Kelemahan Aplikasi Lectora Inspire

Kelemahan yang terdapat pada multimedia berbasis lectora inspire yaitu pengguna awal media lectoraakan sedikit mengalami kesulitan dalam pengoperasian aplikasi lectora, apalagi guruguru yang tidak terlalu mahir menggunakan computer dalam pembelajaran. Dibutuhkan waktu untuk mempelajari fitur-fitur serta cara penggunaanya. Pada awal mengunduh lectora versi trial hanya berlaku 30 hari, sehingga apabila waktu pemakaian lebih dari 30 hari maka lectora tidak dapat digunakan untuk mengedit maupun membuat media pembelajaran kecuali apabila telah 
membeli aplikasi secara penuh pada website resmi lectora. Kemudian apabila prosesor pada computer lambat, maka akan berpengaruh pula terhadap kecepatan aplikasi ketika digunakan.

Kekurangan lainnya dari media ini yaitu media lectora harus didukung dengan adanya LCD dan computer untuk menjalankannya. Jadi apabila disekolah yang tidak terdapat fasilitas LCD Dan computer maka media lectora tidak dapa digunakan.

2. Kelebihan Aplikasi Lectora Inspire

Kelebihan aplikasi lectora inspire yaitu terdapat banyak fitur yang memudahkan pengguna untuk membuat multimedia (gambar, animasi, audio, video) pembelajaran. Lectora memiliki memiliki fitur yang cukup lengkap, mulai dari menyisipkan gambar, audio, video, maupun game edukatif. Selain itu, salah satu kelebihan lectora inspire lainnya adalah terletak pada kemampuan untuk menyisipkan suatu lembar test berupa soal-soal evaluasi, dimana terdapat beberapa jenis soal-soal evaluasi pada lectora diantaranya yaitu True or False (soal benar salah), Multiple Choice (soal pilihan ganda), Multiple Response (soal memilih beberapa jawaban benar), Fill in the Blank (soal mengisi jawaban pendek), serta dapat mengetahui hasil evaluasinya secara langsung.

Telah dilengkapi dengan berbagai contoh model desain tampilan background atau template dengan tampilan grafik yang menarik sehingga pengguna dapat memilih contoh model sesuai keinginan. Selain itu game edukatif yang terdapat pada lectora juga bervariasi seperti basket ball, bowling, hangman, caracterrace, mountainclimb, walktheplank dan sebagainya, yang tertunya dapat menarik perhatian dan minat siswa dalam mengerjakan latihan soal dengan cara asik dan menarik yaitu dengan permainan game.

\section{Kesimpulan}

Berdasarkan hasil pengembangan media pembelajaran interaktif lectora inspire pada mata pelajaran Fiqih bab shalat dalam keadaan darurat kelas VII MTs Al-Kautsar Srono adalah sebagai berikut.

1. Penelitian pengembangan multimedia interaktif lectora inspireini menggunakan langkahlangkah Borg and Gall, namun hanya terbatas pada langkah ke sembilan yaitu revisi produk dan hasil akhir produk, karena penelitian ini bertujuan untuk menghasilkan produk, serta menguji keefektifan produk. Adapun produk media lectora inspireini didalamnya terdapat1.Halamanawal,2.Petunjuk Penggunaan, 3.Menu utama, 4.Kompetensi, 5.Materi, 6.Evaluasi, 7. Pemainan, dan 8.Biografi Penyusun.

2. Efektifitas penggunaan media pembelajaran menggunakan multimedia interaktif lectora inspire pada mata pelajaran fiqih babsholat dalam keadaan darurat di Mts Al-Kautsar Srono ini diukur berdasarkan perbandingan nilai pre-test dan post-test. Untuk mengetahui apakah terdapat 
perbedaan yang signifikan antara hasil pre-test dan post-test yang digunakan dalam pembelajaran maka digunakan perhitungan uji t dengan menggunakan aplikasi SPSS versi 20. Berdasarkan hasil uji t diperoleh nilai Sig. 0,000 $<0,05$ maka HO ditolak dan HA diterima. Jadi ada perbedaan yang signifikan antara hasil pre-test dan post-test. Sehingga media lectorainspire efektif digunakan dalam pembelajaran fiqih kelas VII di MTs Al-Kautsar Srono.

\section{Referensi}

Abidin, Slamet dan Suyono, Moh. 1998. Fiqib Ibadah. CV Pustaka Setia: Bandung.

Annas, Aswar. Interaksi Pengambilan Keputusan dan Evaluasi Kebujakan. Celebes Media Pustaka.

Bahri, Syaiful dan Zain, Azwan. 2010. Strategi Belajar Mengajar. Rineka Cipta: Jakarta.

Departemen Agama RI. 2011. Al-HidayahAl-Qur'an Tafsir Perkata Tajwid Kode Angka. PT Kalim: Tangerang Selatan.

Fasthea, Sholeh, dkk. 2015. Merancang Desain Multimedia Pembelajan Interaktif Menggunakan Software Lectora Inspire. UIN Sunan Kalijaga: Yogyakarta.

Hadi, Nor. 2012 .Panduan Shalat dalam Keadaan Darurat. RuangKata imprint Kawan Pustaka: Bandung.

Munir. 2012. Multimedia Konsep \& Aplikasi dalam Pendidikan. Alfabeta: Bandung.

Mutjaba, Saifuddin. 2013. Ilmu Fiqh Sebuah Pengantar. STAIN Jember Press: Jember.

Ramadhan, Akbar dan Wanarti, Puput. (2005).Pengembangan Media Pembelajaran Menggunakan Multimedia Interaktif Lectora Inspire pada Mata Pelajaran Teknik Elektronika Dasar di SMK Negeri 3 Jombang. Jurnal Pendidikan Teknik Elektro, Volume 04 Nomor 02 Tahun 2015. Universitas Negeri Surabaya.

Rasyid, Sulaiman. 2014. Fiqh Islam. Sinar Baru Algesindo : Bandung.

Riduwan. 2015. Skala Pengukuran V ariabel-V ariabel Penelitian. Alfabeta:Bandung.

Rusman. 2017 . Belajar dan Pembelajaran Berorientasi Standar Proses Pendidikan. PT Kharisma Putra Utama : Jakarta.

Setiono, Aiman dan Agung, Yudha Anggana. (2015).Pengembangan Media Pembelajaran Berbasis Lectora Inspire pada Mata Pelajaran Teknik Elektronika Dasar di SMK Negeri 3 Surabaya. Jurnal Pendidikan Teknik Elektro Volume 04 Nomer 03

Suparno, Paul.20018. Riset Tindakan untuk Pendidik. PT Grasindo: Jakarta

Thobroni, M. 2015. Belajar \& Pembelajaran Teori dan Praktik. Ar-Ruzz Media: Yogyakarta.

Uhbiyati, Nur. 1997. Ilmu Pendidikan Islam II. CV Pustaka Setia: Bandung

Zuhaili, Wahbah. 2012. Fiqih Imam Syafi'I 1. PT Niaga Swadaya: Jakarta 